\title{
Analisis Kesalahan Mahasiswa Pendidikan Matematika Dalam Menyelesaikan Soal Pertidaksamaan Pada Mata Kuliah Kalkulus I
}

\author{
Ana Rahmawati \\ Unipdu Jombang: anarahmawati@mipa.unipdu.ac.id
}

\begin{abstract}
This research is qualitative descriptive research. This research has purpose to describe student error in resolving matter inequality of calculus I. The subject of this research is taken from student of mathematics education Unipdu semester II academic year 2016/2017. Data collection method used in this research is using test method and interview method. Before the researchers conducted the analysis, the researchers examined the validity of data using time triangulation to obtain valid data. Then from the data that has been validly analyzed new then drawn a conclusion. From result of research got result that 1) Subject A do 9 kind of errors, that is: error in determining condition of a root, mistake in doing process calculation, error determines value $x$ on a number line, mistake determines set of settlement, error in determining sign interval at Line of numbers, errors in determining the completion region on the line of numbers, the error in determining the value of the zero maker on the split points, the error in determining the value of the zero-maker on the number line, the error of not continuing the completion process; 2) Subject B performs 8 types of errors, the type of error is the same as subject $A$, except error in determining the requirements of a root.
\end{abstract}

Keywords: Analysis; error; calculus; inequality.

\begin{abstract}
Abstrak
Penelitian ini mempunyai tujuan untuk mendeskripsikan kesalahan mahasiswa dalam menyelesaikan soal pertidaksamaan pada mata kuliah kalkulus I. Penelitian ini penelitian deskriptif kualitatif. Adapun subjek dalam penelitian ini diambil dari mahasiswa pendidikan matematika Unipdu semester II tahun akademik 2016/2017. Metode pengumpulan data yang digunakan pada penelitian ini adalah menggunakan metode tes dan metode wawancara. Sebelum peneliti melakukan analisis, peneliti memeriksa keabsahan data menggunakan triangulasi waktu agar memperoleh data yang valid. Selanjutnya dari data yang sudah valid baru dianalisis yang kemudian ditarik suatu simpulan. Dari hasil penelitian didapat hasil bahwa 1) Subjek A melakukan 9 jenis kesalahan, yaitu: kesalahan dalam menentukan syarat suatu akar, kesalahan dalam melakukan proses perhitungan, kesalahan menentukan nilai $x$ pada suatu garis bilangan, kesalahan menetukan himpunan penyelesaian, kesalahan dalam menentukan tanda interval pada garis bilangan, kesalahan dalam menetukan daerah penyelesaian pada garis bilangan, kesalahan dalam menentukan nilai pembuat nol di ruas kiri (split points), kesalahan dalam menentukan nilai pembuat nol pada garis bilangan, kesalahan tidak melanjutkan proses penyelesaian; 2) Subjek B melakukan 8 jenis kesalahan, jenis kesalahannya sama seperti subjek A, kecuali kesalahan kesalahan dalam menentukan syarat suatu akar.
\end{abstract}

Kata Kunci: Analisis; kesalahan; kalkulus; pertidaksamaan 


\section{PENDAHULUAN}

Kajian mengenai kalkulus sangatlah luas, oleh sebab itu dalam buku pedoman pendidikan program studi pendidikan matematika Unipdu, kalkulus dibagi menjadi kalkulus 1, kalkulus II dan kalkulus peubah banyak. Mata kuliah kalkulus I merupakan salah satu mata kuliah wajib yang ditempuh oleh mahasiswa pada semester II sebagai mata kuliah prasyarat untuk mata kuliah yang lain, misalnya kalkulus II dan analisis real.

Adapun materi yang dikaji pada kalkulus I diantaranya adalah materi pendahuluan yang terdiri dari sistem bilangan real, pertidaksamaan, nilai mutlak, induksi matematika, fungsi. Selanjutnya materi inti yang terdiri dari limit dan kekontinuan, titik ekstrim dan titik belok, derivatif. Berdasarkan data dari hasil ujian tengah semester maupun akhir semester pada tahun sebelumnya, didapatkan hasil bahwa nilai beberapa mahasiswa pada mata kuliah kalkulus I pendidikan matematika kurang memuaskan. Hal tersebut dikarenakan beberapa mahasiswa melakukan kesalahan dalam mengerjakan soal terkait mata kuliah kalkulus I, salah satunya pada bab pertidaksamaan. Materi pertidaksamaan sebenarnya telah dipelajari oleh mahasiswa pada saat jenjang sekolah menengah pertama dan atas, tetapi kenyataannya masih banyak mahasiswa melakukan kesalahan dalam menyelesaikan soal pertidaksamaan.

Kesalahan adalah suatu bentuk penyimpangan terhadap jawaban yang sebenarnya yang bersifat sistematis (Ardiawan, 2015). Analisis kesalahan adalah suatu upaya untuk mengamati, menemukan, dan mengklasifikasi kesalahan dengan aturan tertentu (Astuty \& Wijayanti, 2013). Sebagaimana menurut (Astuty \& Wijayanti, 2013; Siswandi \& Sujadi, 2016; Umam, 2014) Kesalahan-kesalahan peserta didik perlu dianalisis untuk mengetahui beragam kesalahan yang dilakukan oleh peserta didik. Melalui analisis tersebut akan diperoleh jenis dan letak kesalahan, sehingga pendidik dapat memberikan solusi yang tepat agar dapat diperbaki dan tidak terulang lagi dan informasi kesalahan dalam menyelesaikan soal-soal matematika dapat digunakan untuk meningkatkan efektivitas pembelajaran matematika.

Penelitian mengenai analisis kesalahan juga telah banyak dilakukan diantaranya: analisis kesalahan dalam menyelesaikan soal matematika (Istiqomah, 2016), menyelesaikan soal induksi matematika (Ardiawan, 2015), dalam pemecahan masalah divergensi tipe membuktikan (Widodo, 2013) dan analisis kesalahan mahasiswa pada mata kuliah prasyarat kalkulus 1 sebelumnya juga telah dilakukan oleh (Abidin, 2012) pada soal trigonometri.

Berdasarkan uraian penjelasan dan penelitian terdahulu, perlu adanya analisis tentang kesalahan mahasiswa dalam menyelesaikan soal pertidaksamaan pada mata kuliah Kalkulus I agar dapat mengetahui dan mengidentifikasi yang selanjutnya mendeskripsikan secara lebih jelas kesalahan apa saja yang dilakukan oleh mahasiswa. Disamping itu pada penelitian ini juga akan digali kenapa mahasiswa melakukan kesalahan tersebut, agar para pengajar mengetahui penyebab mahasiswa melakukan kesalahan dan dapat memperbaiki melalui pembelajaran. 


\section{METODE PENELITIAN}

Penelitian ini merupakan penelitian deskriptif kualitatif. penelitian ini mempunyai tujuan untuk mendeskripsikan kesalahan mahasiswa dalam menyelesaikan soal pertidaksamaan pada mata kuliah kalkulus I. Adapun subjek dalam penelitian ini diambil dari mahasiswa pendidikan matematika Unipdu semester II tahun akademik 2016/2017 dengan kriteria:1) jawaban mahasiswa mewakili kesalahan yang banyak dilakukan oleh mahasiswa, 2) jawabannya relatif relevan dengan soal tes, 3) mempunyai komunikasi yang baik.

Instrumen utama dalam penelitian ini adalah peneliti sendiri, karena dalam penelitian ini peneliti sebagai penentu dalam mengumpulkan, menganalisis dan menyajikan data. Sedangkan instrumen bantu dalam penelitian ini adalah soal tes pertidaksamaan dan pedoman wawancara.

Teknik pengumpulan data yang digunakan pada penelitian ini adalah tes dan wawancara. Adapun tes yang digunakan berupa pemberian soal bentuk uraian terkait materi pertidaksamaan, diberikan kepada semua mahasiswa pendidikan matematika yang memrogram mata kuliah kalkulus I. Tes tersebut diberikan setelah memperoleh materi pertidaksamaan. Wawancara pada penelitian ini adalah dengan cara mewawancarai subjek berdasarkan hasil tertulisnya terhadap soal yang diberikan, bertujuan untuk mengklarifikasi jawaban tertulis subjek dan untuk memperoleh informasi penyebab mahasiswa melakukan kesalahan. Pedoman wawancara bersifat tidak terstruktur karena peneliti tidak menggunakan pedoman wawancara yang telah tersusun secara sistematis dan lengkap untuk mengumpulkan data, tetapi pedoman wawancara yang digunakan hanya berupa garis-garis besar permasalahan yang akan ditanyakan (Sugiyono, 2016). Pertanyaan yang diberikan peneliti tidak harus sama untuk setiap subjek, tetapi tergantung dengan banyaknya informasi yang dibutuhkan oleh peneliti. Sebelum peneliti melakukan analisis, peneliti memeriksa keabsahan data menggunakan triangulasi waktu agar memperoleh data yang valid. Selanjutnya dari data yang sudah valid baru dianalisis yang kemudian ditarik suatu simpulan.

\section{HASIL PENELITIAN DAN PEMBAHASAN}

Mahasiswa diberikan soal uraian terkait materi pertidaksamaan, setelah mahasiswa memperoleh materi tersebut. Mahasiswa tidak diperbolehkan membuka buku catatan selama mengerjakan soal tersebut. Berikut ini adalah soal yang diberikan kepada mahasiswa, yaitu:

Jika $x \in \mathbb{R}$, tentukan himpunan penyelesaian dari:

$$
\begin{array}{ll}
\text { a. } & \sqrt{1-3 x}<\sqrt{2 x+5} \\
\text { b. } & (4-x)^{2}(x+1)^{3}>0 \\
\text { c. } & |2 x-1| \geq|x+1| \\
\text { d. } & 2|2 x-3|<|x+10|
\end{array}
$$

Setelah semua mahasiswa mengerjakan soal tersebut, selanjutnya peneliti menelaah jawaban mahasiswa untuk mendapatkan subjek penelitian. Berdasarkan kriteria yang sudah ditetapkan oleh peneliti, terdapat 2 mahasiswa yang memenuhi kriteria yang telah ditetapkan. Kedua mahasiswa tersebut disimbolkan dengan subjek A dan subjek B. Setelah memperoleh dua subjek selanjutnya peneliti mewawancarai subjek terkait jawaban tertulisnya. Dan pada 
waktu yang berbeda peneliti memberikan soal pertidaksamaan lagi kepada subjek dan mewawancarainya sesuai dengan jawaban tertulis subjek. Selanjutnya peneliti membandingkan apakah data yang didapat dari tes pertama dengan data yang didapat dari tes yang kedua sesuai, jika sesuai maka data pada tes pertama sudah valid. Setelah memperoleh data yang valid, baru dianalisis.

Berdasarkan pada hasil jawaban tertulis subjek dan dari hasil wawancara subjek berkaitan dengan jawaban tertulisnya, berikut ini disajikan hasil analisis dari subjek penelitian:

1. Subjek A

Berikut ini adalah jawaban tertulis subjek A berdasarkan soal nomor 1:

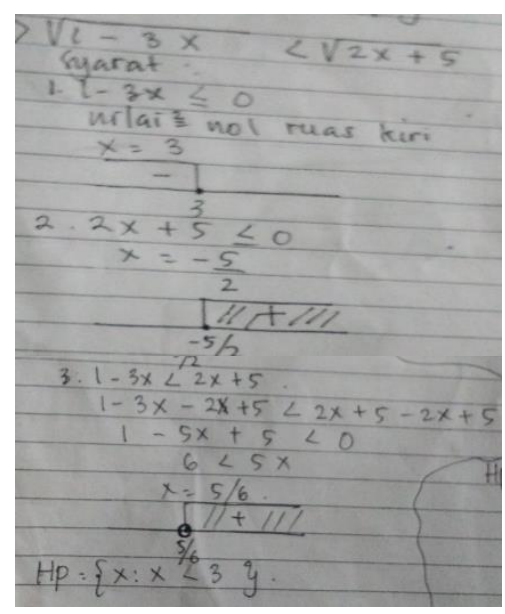

Gambar 1. Jawaban Soal Nomor 1 oleh Subjek A

Berdasarkan hasil dari jawaban tertulis dan wawancara terkait hasil tertulis subjek A, didapatkan beberapa kesalahan yang dilakukan oleh subjek A, yaitu:

1. Kesalahan dalam menentukan syarat suatu akar, seharusnya syarat yang pertama untuk menyelesaikan pertidaksamaan tersebut adalah $1-3 x \geq 0$, dan syarat kedua adalah $2 x+5 \geq 0$ tetapi subjek menuliskan $1-3 x \leq 0$ dan $2 x+5 \leq 0$. Berdasarkan hasil wawancara subjek yakin jika jawabannya sudah tepat, dia menjawab syarat pertama adalah $1-3 x \leq 0$ dan syarat kedua adalah $2 x+5 \leq 0$ karena dalam soal tanda pertidaksamaannya adalah <, sehingga untuk menyelesaikan soal tersebut dia menggunakan tanda $\leq$. Jadi dapat disimpulkan subjek mengalami kesalahan ini karena kurang faham dengan materi terkait pertidaksamaan dalam bentuk akar.

2. Kesalahan dalam melakukan proses perhitungan, yakni dapat dilihat pada gambar 1, poin 3 yaitu subjek mengurangi kedua ruas dengan $-2 x+5$. Seharusnya kedua ruas dikurangi dengan $-2 x-5$. Ketika digali lewat wawancara, subjek melakukan kesalahan tersebut karena kurang teliti dalam menyelesaikan soal tersebut.

3. Kesalahan menentukan nilai-nilai $x$ pada garis bilangan, hal ini terjadi karena subjek melakukan kesalahan pada nomor 1 dan nomor 2 . 
4. Kesalahan dalam menentukan himpunan penyelesaian, hal ini terjadi karena subjek mengalami kesalahan nomor 1, 2 dan nomor 3 sehingga himpunan penyelesaiannya pun menjadi kurang tepat.

Berikut ini adalah jawaban tertulis subjek A berdasarkan soal nomor 2:

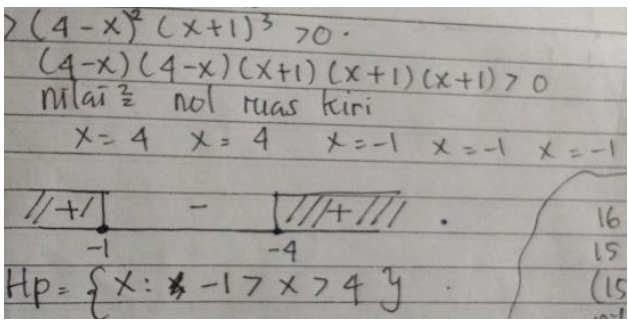

Gambar 2. Jawaban Soal Nomor 2 oleh Subjek

Berdasarkan hasil dari jawaban tertulis dan wawancara terkait hasil tertulis subjek A pada soal nomor 2, didapatkan beberapa kesalahan yang dilakukan oleh subjek A, yaitu:

1. Kesalahan menentukan nilai-nilai $x$ pada garis bilangan, terlihat dari jawaban subjek A, sebenarnya subjek sudah dapat menentukan split points atau menentukan nilai pembuat nol di ruas kiri tetapi subjek mengalami kesalahan menuliskan nilai $x$ pada garis bilangan. Seharusnya nilai $x$ pada garis bilangan adalah -1 dan 4 , tetapi subjek menuliskan -1 dan -4 pada garis bilangan. Ketika diwawancarai alasan subjek melakukan kesalahan ini adalah karena dia lupa dan kurang teliti.

2. Kesalahan dalam menentukan tanda interval pada garis bilangan, terlihat dari jawaban subjek seharusnya interval $(-\infty,-1)$ bertanda negatif, interval $(-1,4)$ bertanda positif dan interval $(4, \infty)$ juga bertanda positif. Subjek melakukan kesalahan ini karena dia bingung menentukan tanda pada tiap-tiap interval.

3. Kesalahan dalam menentukan daerah penyelesaian pada garis bilangan, hal ini terjadi karena subjek melakukan kesalahan nomor 1 dan 2 .

4. Kesalahan dalam menentukan himpunan penyelesaian, ini terjadi karena subjek A melakukan kesalahan nomor 1, 2 dan kesalahan nomor 3.

Berikut ini adalah jawaban tertulis subjek A berdasarkan soal nomor 3:

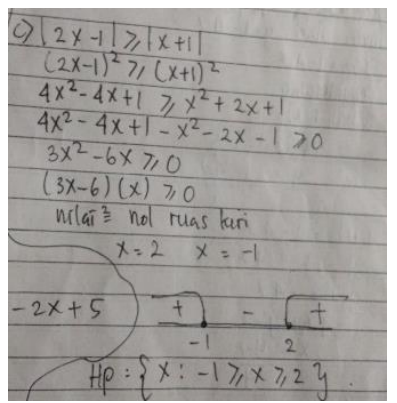

Gambar 3. Jawaban Soal Nomor 3 oleh Subjek A 
Berdasarkan hasil dari jawaban tertulis dan wawancara terkait hasil tertulis subjek A pada soal nomor 3, didapatkan beberapa kesalahan yang dilakukan oleh subjek A, yaitu:

1. Kesalahan dalam menentukan nilai pembuat nol di ruas kiri (split points), yaitu subjek menuliskan nilai $x$ adalah 2 dan -1 , seharusnya nilai $x$ adalah 2 dan 0 . Ketika diwawancarai subjek yakin kalau jawabannya sudah tepat, dan dari wawancara tergali bahwa subjek mengalami kesalahan itu karena subjek masih kurang memahami kalau pertidaksamaan kuadrat diubah ke dalam bentuk faktor dan salah satu faktornya adalah $x$, dia mengira kalau nilai $x$ adalah sama dengan -1 .

2. Kesalahan dalam menentukan nilai pembuat nol (split points) pada garis bilangan. Subjek melakukan kesalahan ini karena subjek melakukan kesalahan pada nomor 1, sehingga berakibat nilai $x$ yang dituliskan pada garis bilangan juga kurang tepat.

3. Kesalahan dalam menentukan daerah penyelesaian pada garis bilangan, hal ini terjadi karena subjek melakukan kesalahan nomor 1 dan 2 .

4. Kesalahan dalam menentukan himpunan penyelesaian, hal ini terjadi karena subjek mengalami kesalahan nomor 1, 2 dan nomor 3 sehingga himpunan penyelesaiannya pun menjadi kurang tepat.

Berikut ini adalah jawaban tertulis subjek A berdasarkan soal nomor 4:

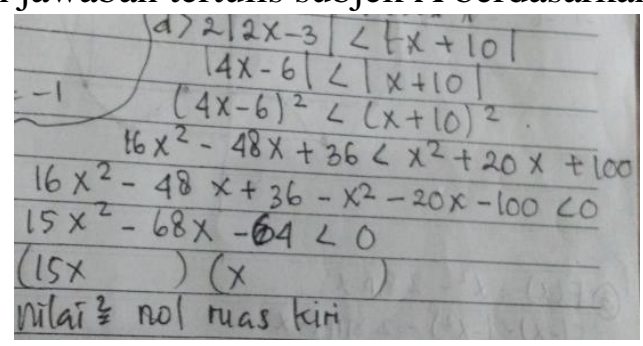

Gambar 4. Jawaban Soal Nomor 4 oleh Subjek A

Berdasarkan hasil dari jawaban tertulis dan wawancara terkait hasil tertulis subjek A pada soal nomor 4, didapatkan kesalahan yang dilakukan oleh subjek A, yaitu: kesalahan tidak melanjutkan proses penyelesaian, terlihat dari gambar 4 bahwa subjek A tidak melanjutkan proses penyelesaiannya. Dari wawancara subjek A juga tidak dapat melanjutkan proses penyelesaiannya karena dia merasa kesulitan menentukan faktor-faktor dari pertidaksamaan kuadrat tersebut. Subjek A mengatakan bahwa angkanya terlalu besar sehingga dia tidak dapat menentukan faktor-faktornya.

Berdasarkan dari hasil analisis tersebut, dapat disimpulkan kesalahan subjek A seperti yang tersaji dalam tabel di bawah ini:

Tabel 1. Deskripsi Kesalahan Subjek A

\begin{tabular}{cl}
\hline No. & \multicolumn{1}{c}{ Deskripsi Kesalahan } \\
\hline 1. & Kesalahan dalam menentukan syarat suatu akar \\
\hline 2. & Kesalahan dalam melakukan proses perhitungan \\
\hline 3. & Kesalahan menentukan nilai $x$ pada suatu garis bilangan \\
\hline 4. & Kesalahan menentukan himpunan penyelesaian \\
\hline
\end{tabular}




\begin{tabular}{cl}
\hline No. & \multicolumn{1}{c}{ Deskripsi Kesalahan } \\
\hline 5. & Kesalahan dalam menentukan tanda interval pada garis bilangan \\
\hline 6. & Kesalahan dalam menentukan daerah penyelesaian pada garis bilangan \\
\hline 7. & Kesalahan dalam menentukan nilai pembuat nol di ruas kiri (split points) \\
\hline 8. & Kesalahan dalam menentukan nilai pembuat nol pada garis bilangan \\
\hline 9. & Kesalahan tidak melanjutkan proses penyelesaian \\
\hline
\end{tabular}

2. Subjek B

Berikut ini adalah jawaban tertulis subjek B berdasarkan soal nomor 1:

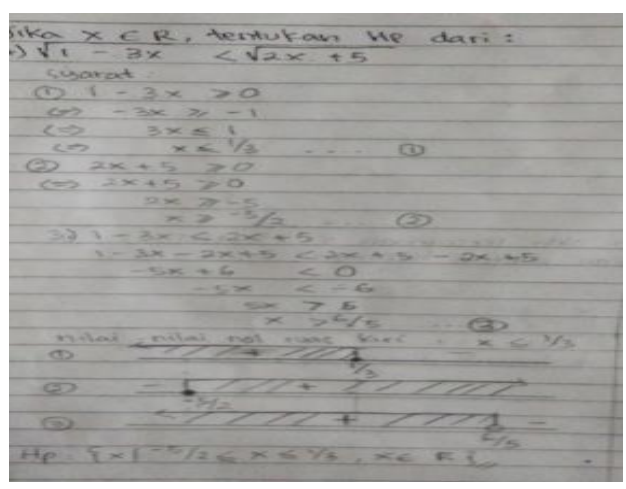

Gambar 5. Jawaban Soal Nomor 1 oleh Subjek B

Berdasarkan hasil dari jawaban tertulis dan wawancara terkait hasil tertulis subjek B pada soal nomor 1, didapatkan beberapa kesalahan yang dilakukan oleh subjek B, yaitu:

1. Kesalahan dalam proses perhitungan, yakni dapat dilihat pada gambar 5, poin 3 yaitu subjek mengurangi kedua ruas dengan $-2 x+5$. Seharusnya kedua ruas dikurangi dengan $-2 x-5$. Ketika digali lewat wawancara, subjek melakukan kesalahan tersebut karena kurang teliti dalam menyelesaikan soal tersebut.

2. Kesalahan menentukan nilai-nilai $x$ pada garis bilangan, hal ini terjadi karena subjek melakukan kesalahan pada nomor 1 .

3. Kesalahan dalam menentukan daerah penyelesaian pada garis bilangan, hal ini terjadi karena subjek melakukan kesalahan nomor 1 dan 2.

4. Kesalahan dalam menentukan himpunan penyelesaian, hal ini terjadi karena subjek mengalami kesalahan nomor 1 dan nomor 2 sehingga himpunan penyelesaiannya pun menjadi kurang tepat.

Berikut ini adalah jawaban tertulis subjek B berdasarkan soal nomor 2:

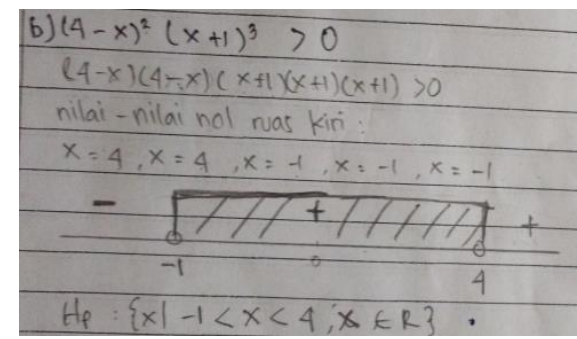

Gambar 6. Jawaban Soal Nomor 2 oleh Subjek B 
Berdasarkan hasil dari jawaban tertulis dan wawancara terkait hasil tertulis subjek B pada soal nomor 2, didapatkan beberapa kesalahan yang dilakukan oleh subjek B, yaitu:

1. Kesalahan dalam menentukan daerah penyelesaian pada garis bilangan, subjek melakukan kesalahan ini karena dia bingung interval $(-1,4)$ dan interval $(4, \infty)$ mempunyai tanda yang sama, yaitu positif semua.

2. Kesalahan dalam menentukan himpunan penyelesaian, ini terjadi karena subjek A melakukan kesalahan nomor 1 .

Berikut ini adalah jawaban tertulis subjek B berdasarkan soal nomor 3:

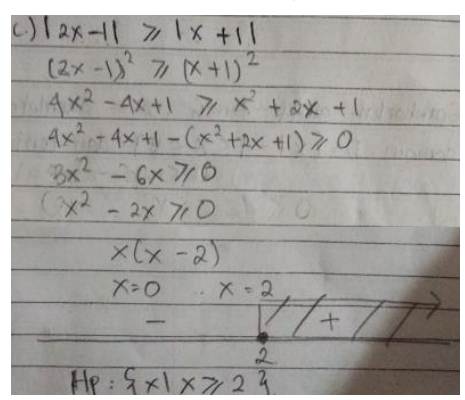

Gambar 7. Jawaban Soal Nomor 3 oleh Subjek B

Berdasarkan hasil dari jawaban tertulis dan wawancara terkait hasil tertulis subjek B pada soal nomor 3, didapatkan beberapa kesalahan yang dilakukan oleh subjek B, yaitu:

1. Kesalahan dalam menentukan nilai pembuat nol pada garis bilangan. Sebenarnya nilai pembuat nol sudah benar, yaitu $x=0$ dan $x=2$, tetapi subjek tidak menuliskan nilai $x=0$ pada garis bilangan karena menurut dia tidak perlu menuliskan nilai tersebut pada garis bilangan karena nilainya nol. Dari peryataan subjek dapat disimpulkan kalau subjek kurang memahami materi pertidaksamaan.

2. Kesalahan dalam menentukan tanda interval pada garis bilangan, karena subjek melakukan kesalahan nomor 1 .

3. Kesalahan dalam menentukan daerah penyelesaian pada garis bilangan, hal ini terjadi karena subjek melakukan kesalahan nomor 1 dan 2.

4. Kesalahan dalam menentukan himpunan penyelesaian, hal ini terjadi karena subjek mengalami kesalahan nomor 1, 2 dan nomor 3 sehingga himpunan penyelesaiannya pun menjadi kurang tepat.

Berikut ini adalah jawaban tertulis subjek B berdasarkan soal nomor 4:

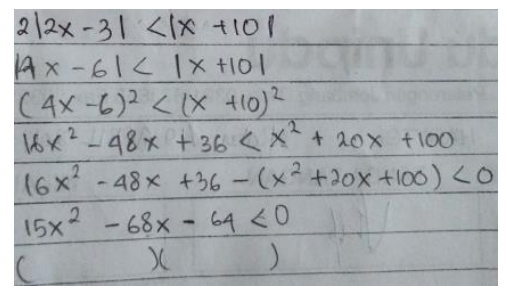

Gambar 8. Jawaban Soal Nomor 4 oleh Subjek B 
Berdasarkan hasil dari jawaban tertulis dan wawancara terkait hasil tertulis subjek B pada soal nomor 4, didapatkan beberapa kesalahan yang dilakukan oleh subjek B, yaitu: kesalahan tidak melanjutkan proses penyelesaian, terlihat dari gambar 4 bahwa subjek B tidak melanjutkan proses penyelesaiannya. Dari wawancara subjek B juga tidak dapat melanjutkan proses penyelesaiannya karena dia merasa kesulitan menentukan faktor-faktor dari pertidaksamaan kuadrat tersebut. Subjek B mengatakan bahwa angkanya terlalu besar sehingga dia tidak dapat menentukan faktor-faktornya.

Berdasarkan dari hasil analisis tersebut, dapat disimpulkan kesalahan subjek B seperti yang tersaji dalam tabel di bawah ini:

Tabel 2. Deskripsi Kesalahan Subjek B

\begin{tabular}{cl}
\hline No. & \multicolumn{1}{c}{ Deskripsi Kesalahan } \\
\hline 1. & Kesalahan dalam melakukan proses perhitungan \\
\hline 2. & Kesalahan menentukan nilai $x$ pada suatu garis bilangan \\
\hline 3. & Kesalahan menentukan himpunan penyelesaian \\
\hline 4. & Kesalahan dalam menentukan tanda interval pada garis bilangan \\
\hline 5. & Kesalahan dalam menentukan daerah penyelesaian pada garis bilangan \\
\hline 6. & Kesalahan dalam melakukan proses perhitungan \\
\hline 7. & Kesalahan dalam menentukan nilai pembuat nol pada garis bilangan \\
\hline 8. & Kesalahan tidak melanjutkan proses penyelesaian \\
\hline
\end{tabular}

Berdasarkan pada tabel 1 dan tabel 2 di atas, subjek A melakukan 9 jenis kesalahan dan subjek B melakukan 8 jenis kesalahan. Dari hasil wawancara dapat diketahui bahwa alasan kenapa subjek A dan subjek B melakukan kesalahan hampir sama. Mereka melakukan kesalahan dikarenakan subjek A dan subjek B kurang memahami materi pertidaksamaan dan kurang teliti dalam mengerjakan soal tersebut. Akibat dari tidak memahami materi pertidaksamaan akhirnya subjek melakukan beberapa kesalahan dalam mengerjakan soal dan tidak memahami soal yang diberikan.

Sebagaimana penelitian oleh (Abidin, 2012) bahwa penyebab terjadi kesalahan mahasiswa dalam menyelesaikan soal Kalkulus I adalah: Mahasiswa tidak bisa menghafal lagi rumus yang akan digunakan, kurang cermat, kurang teliti dalam menjawab, tidak ada persiapan menghadapi tes, tidak ingat lagi cara penyelesaiannya soal bentuk tersebut, dan tidak cukup waktu dalam mengikuti tes.

\section{SIMPULAN DAN SARAN}

Berdasarkan hasil penelitian, dapat disimpulkan bahwa: Subjek A melakukan 9 jenis kesalahan, yaitu: kesalahan dalam menentukan syarat suatu akar, kesalahan dalam melakukan proses perhitungan, kesalahan menentukan nilai $x$ pada suatu garis bilangan, kesalahan menetukan himpunan penyelesaian, kesalahan dalam menentukan tanda interval pada garis bilangan, kesalahan dalam menetukan daerah penyelesaian pada garis bilangan, kesalahan dalam menentukan nilai pembuat nol di ruas kiri (split points), kesalahan dalam menentukan 
nilai pembuat nol pada garis bilangan, kesalahan tidak melanjutkan proses penyelesaian. Subjek B melakukan 8 jenis kesalahan, yaitu: kesalahan dalam melakukan proses perhitungan, kesalahan menentukan nilai $x$ pada suatu garis bilangan, kesalahan menetukan himpunan penyelesaian, kesalahan dalam menentukan tanda interval pada garis bilangan, kesalahan dalam menetukan daerah penyelesaian pada garis bilangan, kesalahan dalam menentukan nilai pembuat nol di ruas kiri (split points), kesalahan dalam menentukan nilai pembuat nol pada garis bilangan, kesalahan tidak melanjutkan proses penyelesaian.

Setelah mengetahui deskripsi kesalahan subjek dalam menyelesaikan soal pertidaksamaan pada mata kuliah kalkulus I, diharapkan dosen dapat memberi penekanan pemahaman konsep materi pertidaksamaan, khususnya dibagian yang mahasiswa sering melakukan kesalahan. Menindaklanjuti penelitian ini dengan cara meneliti analisis kesalahan lebih lanjut dan pemberian scaffolding untuk mengatasinya.

\section{DAFTAR PUSTAKA}

Abidin, Z. (2012). Analisis Kesalahan Mahasiswa Prodi Pendidikan Matematika Fakultas Tarbiyah IAIN Ar-Raniry Dalam Mata Kuliah Trigonometri dan Kalkulus 1. Jurnal Ilmiah Didaktika, 13(1), 183-196.

Ardiawan, Y. (2015). Analisis Kesalahan Mahasiswa Dalam Menyelesaikan Soal Induksi Matematika di IKIP PGRI Pontianak. Jurnal Pendidikan Informatika Dan Sains, 4(1), $147-163$.

Astuty, K. Y., \& Wijayanti, P. (2013). Analisis Kesalahan Siswa Kelas V Dalam Menyelesaikan Soal Matematika Pada Materi Pecahan di SDN Medokan Semampir I/259 Surabaya. MATHEdunesa, 3(2), 1-7.

Istiqomah, N. (2016). Analisis Kesalahan Dalam Menyelesaikan Soal Matematika Siswa Kelas Xi SMK Tamtama Karanganyar Tahun Ajaran 2013/2014. UNION: Jurnal Pendidikan Matematika, 4(2), 343-352.

Sahriah. (2012). Analisis Kesalahan Siswa dalam Menyelesaikan Soal Matematika Materi Operasi Pecahan Bentuk Aljabar Kelas VIII SMP Negeri 2 Malang. Jurnal Pendidikan Matematika, 1(1).

Siswandi, E., \& Sujadi, I. (2016). Analisis Kesalahan Siswa Dalam Menyelesaikan Masalah Matematika Kontekstual pada Materi Segiempat Berdasarkan Analisis Newman Ditinjau dari Perbedaan Gender (Studi Kasus pada Siswa Kelas VII SMPN 20 Surakarta). Jurnal Elektronik Pembelajaran Matematika, 4(7), 633-643.

Sugiyono. (2016). Metode Penelitian Pendidikan (Pendekatan Kuantitatif, Kualitatif, dan $R \& D)$. Bandung: Alfabeta.

Umam, M. D. (2014). Analisis Kesalahan Siswa Dalam Menyelesaikan Soal Cerita Matematika Materi Operasi Hitung Pecahan. MATHEdunesa, 3(3), 131-134.

Widodo, S. A. (2013). Analisis Kesalahan Dalam Pemecahan Masalah Divergensi Tipe Membuktikan pada Mahasiswa Matematika. Jurnal Pendidikan Dan Pengajaran, 46(2). 